\title{
The concentration of urban crime in space by race: Evidence from South Africa
}

\author{
GREGORY D. BREETZKE
}

Gregory Dennis Breetzke

Associate Professor, Department of Geography, Geoinformatics and Meteorology, University of Pretoria, Pretoria, 0002, South Africa (Tel: 002712420 4318; Fax: 002712420 6385; E-mail: greg.breetzke@ up.ac.za)

\begin{abstract}
Crime inequality in neighborhoods by race is commonly blamed on social inequalities borne out of segregation and economic discrimination. South Africa is a country synonymous with racial-spatial segregation and discrimination as a result of legislatively enforced policies of the former apartheid government. This study examines whether urban crime inequalities by race exist in the city of Tshwane, South Africa and applies the social disorganization theory to identify the empirical causes of these crime inequalities. Violent and sexual crime was found to concentrate in Black African neighborhoods, while property crime was concentrated in neighborhoods classified as 'Mixed'. The causes of crime in neighborhoods were found to vary across racial groups with results suggesting non-uniformity in the extent to which the various social disorganization constructs impact crime based on race. The results of this study challenge the notion that segregation and economic discrimination uniformly impacts affected communities. Explanations for the descriptive and empirical findings are provided in the context of an increasingly eclectic post-apartheid South African city.
\end{abstract}

Keywords: Crime, race, segregation, South Africa 


\section{Introduction}

It is well-established that crime clusters in space. This is one of the theoretical underpinnings of the school of environmental criminology which argues that if the environment did not influence human behavior, crime rates would be distributed equally across the geographical structure, which of course they are not (Siegel, 2001). Three main theoretical perspectives housed within the school of environmental criminology play a central role in understanding the relationship between crime and space: the routine activities theory (Cohen \& Felson, 1979), rational choice theory (Cornish \& Clarke, 1986), and crime pattern theory (Brantingham \& Brantingham, 1991). Although inherently different the general premise of these theoretical frameworks are the same in that they attempt to spatially link offenders with crime opportunities. The main aim of these and other spatial theories of crime are to identify what makes a place criminogenic, or rather, at an increased risk for criminal victimization. Understandably, a plethora of studies have been forthcoming over the past few decades examining the association between crime and space. Notably, these studies have taken place at increasingly finer levels of spatial aggregation; the finest being the street segment where researchers have examined how the configuration (Davies \& Johnson, 2015), permeability (Wu, Liu, Ye, Leipnik, Lee, \& Zhu, 2015), and socio-demographic character (Weisburd, Groff, \& Yang, 2012) of street segments increase the risk of various types of criminal victimization. At a broader level, a number of studies have explored the causes of variation in crime rates using spatial data with the 'neighborhood' as a unit of analysis. In these studies the 'neighborhood' is an administratively defined spatial boundary such as a census tract, suburb, census areal unit or some other arbitrary measure depending on the geographical focus area under investigation. As anticipated by environmental criminology theory, the

general consensus of this literature is that crime is spatially clustered and is largely a consequence of various social and economic endogenous factors such as deprivation 
(Andresen, 2006; Boyle \& Hassett-Walker, 2008), family composition (Ingram \& da Costa, 2015); residential mobility (Breetzke \& Horn, 2006), and collective efficacy (Morenoff, Sampson, \& Raudenbush, 2001), among numerous others.

One aspect of the social environment that has received considerable attention in examining neighborhood level crime risk is the racial and/or ethnic composition of communities. In fact, race has been a major focus of urban crime researchers, particularly in the United States (US). Initially deterministic in nature (see Brearley, 1932), explanations for the spatial clustering of crime in minority mostly non-White neighborhoods in the US have changed from a more cultural perspective (see Curtis 1975; Wolfgang \& Ferracuti, 1967) to a more social structural approach. The latter largely as a result of the structural perspectives advocated by Merton's (1938) social structure and anomie thesis and later Shaw and McKay's (1942) social disorganization theory. These perspectives view group differences in crime and violence as stemming from inequality in socioeconomic conditions such as poverty and deprivation. Indeed, the social disorganization theory was the first placed-based theory of crime that showed how circumstances like deprivation and mobility in neighborhoods gave rise to crime and delinquency rather than the neighborhood's racial/ethnic make-up. In their now seminal work, Shaw and McKay painstakingly hand mapped the residential locations of thousands of juvenile delinquents in Chicago, Philadelphia and other cities in the US, and noted how areas with high levels of residential turnover, deprivation and ethnic heterogeneity within cities yielded the highest delinquency rates regardless of the race and ethnicity of people residing there. They suggested that there was a withdrawal in community social control activities in areas with mobile, deprived and diverse populations and this increased the risk of criminality of young people. In short, the same structural processes explained crime and delinquency regardless of the locale under investigation. The work of the structural theorists provided the empirical basis for contemporary research focusing on placed-based 
effects on crime rather than person-based effects. Later, other macrostructural factors such as concentrated disadvantage (Sampson, 1987; Shihadeh \& Ousey, 1998), segregation (Peterson \& Krivo, 1993), inequality (Krivo \& Peterson, 2000), migration (Martinez, 2002), and labor market context (Crutchfield, 1995), differentially impact crime by race. This has led to general support for the racial invariance hypothesis - the notion that structural variables predict violent crime in the same way for all racial and ethnic groups.

Studies examining the concentration of crime by space and race have however largely been confined to the US and, to a lesser extent, Europe. This is a drawback of much past urban crime research since studies in other contexts could provide additional support and/or important points of difference for the plethora of past mainly 'Western' race-crime theories, theses, hypotheses, and assumptions developed. Countries, especially in less developed contexts, differ culturally, socially, economically and politically from the US and Europe yet certain well-established spatial perspectives, patterns or theories on race and crime may still hold true. In this study we use the seminal social disorganization theory as a framework to investigate the concentration of urban crime in space by race in a country synonymous with urban fragmentation and segregation drawn primarily along racial lines.

\section{South Africa and social disorganization}

Race, space, and crime are inextricably linked in South Africa, both past and present. Under the era of apartheid (1951 - 1994) the country's diverse population was spatially segregated according to certain state-defined racial groups. This contrived socio-spatial redesign coupled with other legislatively enforced planning policies not only racialized South African cities but led to the concentrated disadvantage of the majority Black African ${ }^{1}$ population in certain segregated geographical neighborhoods. These so-called 'township' areas occurring distant and distinct from the Whites-only urban core and were typically characterized by widespread 
malnutrition, poor or non-existent health systems, ill-equipped and overcrowded schools, inadequate or non-existent social security, and high levels of unemployment (see Chikane, 1986). Anecdotally, these areas were also the location of the vast majority of crime occurring during this period (see Altbeker, 2007; Breetzke, 2012; Elder, 2003; Kynoch, 2005).

The dawn of democracy in April 1994 and the concomitant promise of a new life for all raised popular expectations among the majority of South Africans of a non-racist, nonprejudiced society; hence the term - 'Rainbow Nation' - coined by the Archbishop Desmond Tutu shortly after the democratic transition. The official repeal of the Group Areas Act of 1950 (Act 41) - an Act that instituted the separate socio-spatial development of the country's cities by race - allowed for the now free movement of the whole South African population and, at least theoretically, desegregation. More than twenty years into democracy and South Africa's urban spatial transformation has been described as sluggish (Hamann \& Horn, 2015) and idiosyncratic (Harrison, \& Todes, 2015). Desegregation that has occurred has mainly taken place in poorer inner-city areas driven largely by rural-urban migration; or in middle to higher income former Whites-only neighborhoods on the urban periphery driven by class and the markets. As Mabin $(2005$, p. 52) states, “...the paths out of the townships are little trodden by outsiders moving in" as a "nouveau riche cohort" (Rex, Campbell, \& Visser, 2014, p.5) of Black Africans leave previously designated township areas and increasingly occupy more affluent former Whites-only neighborhoods. Meanwhile, townships still face major challenges related to healthcare, education and housing service delivery that have not dissipated more than twenty years into democracy (Jürgens \& Donaldson, 2012).

The geographical focus area of this study, Tshwane ${ }^{2}$, has remained highly segregated (see Figure 1) and in some regions of the city segregation has in fact increased over the past twenty years (Hamman \& Horn, 2015). This is mainly a result of socio-economic circumstances which have limited the ability of particularly the Black African population to 


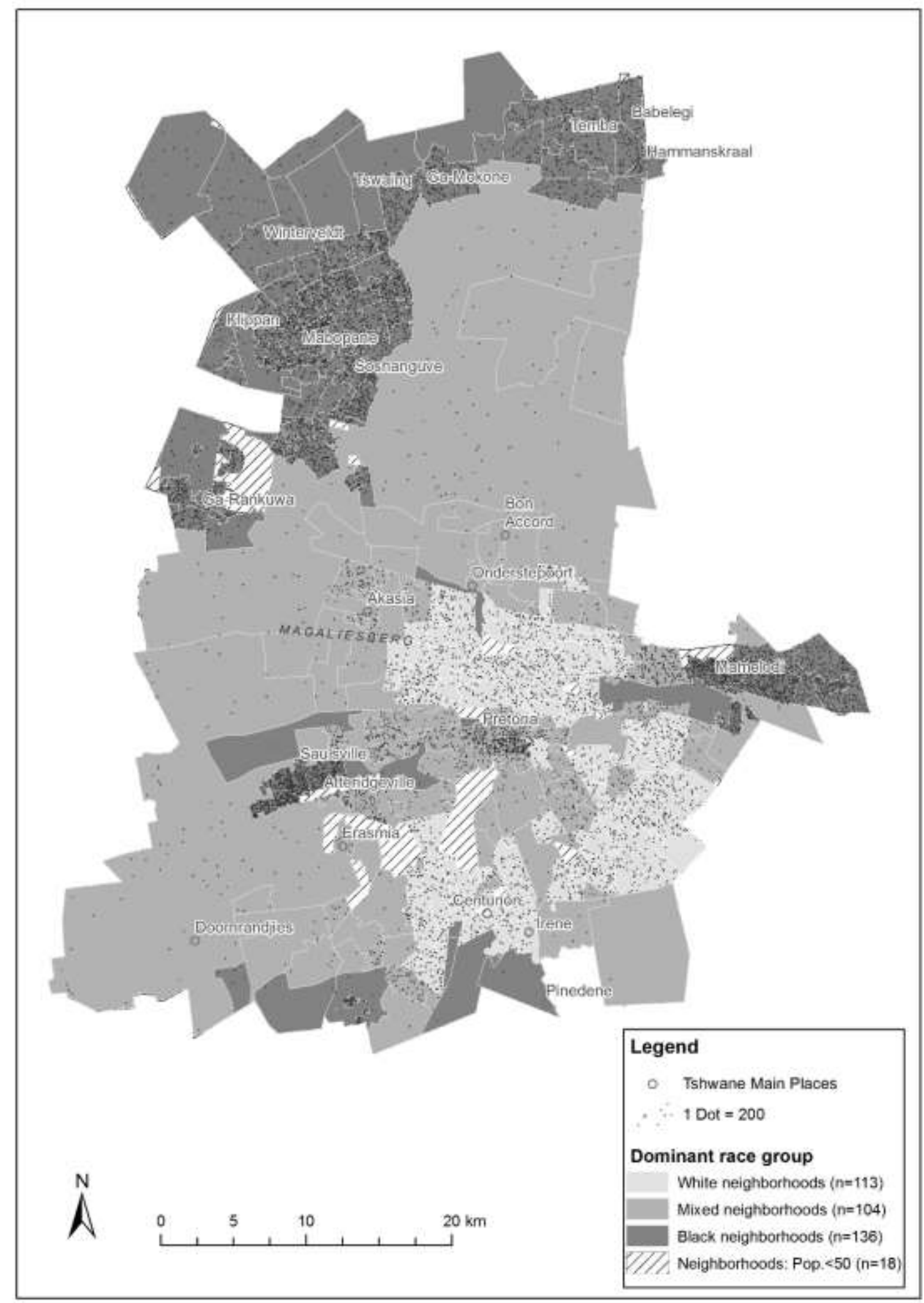

Figure 1: The city of Tshwane by race 
move into more affluent former Whites-only neighborhoods (see Hamann \& Horn, 2015) and the retreat of particularly the White population into gated neighborhoods (Breetzke, Landman \& Cohn, 2014). The city of Tshwane is the capital city of South Africa and is located in the central Gauteng province. The city has a diverse social and economic structure and is a wellestablished destination for individuals arriving into the country, or from outside the province in search of employment. Breetzke \& Horn (2006) note that it is this lure of employment and wealth in Tshwane from migrants that can be used to explain the magnitude and nature of crime in the city.

A number of studies have indicated that crime is post-apartheid South Africa is still primarily located in Black African township areas (see Breetzke, 2010; Schwabe \& Schurink, 2000). Overall crime levels remain high in the country post-apartheid despite a 'honeymoon period' (Berg \& Schärf, 2004, p. 61) from 1994-1996 during which crime levels dropped and momentarily stabilized. Explanations for the rise or continued high levels of crime in postapartheid South African cities are myriad and include rising levels of poverty (Maree, 2003), unemployment (Blackmore, 2003; Brown, 2001), income inequality (Demombynes and Özler, 2005) as well as the ready availability of alcohol, illegal drugs and firearms (Berg and Schärf, 2004; Maree, 2003). Another more common explanation for the high crime rates in post-apartheid South Africa have linked the country's unique socio-political history to ineffective social control mechanisms that imply high levels of social disorganization within certain communities (Berg \& Schärf, 2004; Elder, 2003; Emmett, 2003; Maree, 2003). Accordingly, a chain reaction was set in place under apartheid, which has seen a selfreinforcing cycle in which levels of crime and delinquency within certain regions of the country have created an ecological context that favours their perpetuation. There can be little doubt that the apartheid's urban spatiality gave rise to socially disorganized communities which were almost exclusively Black African. According to Emmett (2003) not only did 
social disorganization lead to the breakdown of informal social control in Black African communities but also weakened the capacity of these communities to protect themselves against crime. This resulted in the continued rise of crime in these communities that has not dissipated in the post-apartheid-era.

Kubrin and Weitzer (2003) outline four new substantive directions for social disorganization theory. Among those directions is the need for researchers to be cognisant of the urban political economy of the area under investigation. According to the researchers the urban political economy has received almost no attention in the social disorganization literature despite neighborhoods being largely shaped by urban political and economic forces. Indeed, the priorities and decisions of local and national governments and business interests can have major effects on a neighborhood's quality of life and that neighborhoods vary in their capacity to secure valued city services. There are few other countries in the world in which national and local governmental policies have had such a dramatic effect on shaping the urban environment, and possible consequences thereof, than South Africa; and even less in which the criteria governing the urban political economy of cities is race. Despite this few empirical studies have been forthcoming in the country examining the possible causes and consequences of the racially-stratified spatial urban layout in South Africa on crime levels.

\section{The current study}

The current study examines the spatial concentration of crime in the city of Tshwane, South Africa by race and aims to identify the empirical causes of these concentrations using the social disorganization theory as the theoretical backcloth. The spatial concentration of crime in Tshwane is first examined using the Pareto principle or " $80 / 20$ " rule which states that $80 \%$ of some kinds of outcomes are the results of only $20 \%$ of the related causes. In the urban criminological literature the principle is employed in three main contexts, first, repeat 
criminals, where the notion is that $80 \%$ of the crimes in any given community are committed by $20 \%$ of the criminals; second, repeat victims, whereby $80 \%$ of the crimes victimizes $20 \%$ of the victims of crime, and third, crime hotspots where $80 \%$ of the crimes happen in $20 \%$ of a given policing precinct. We determine whether the principle applies to crime occurring across the city as a whole and then examine whether the principle applies to neighborhoods stratified by race. Next, we use spatial regression models to identify the empirical causes of these crime concentrations by race. Tshwane is the capital city of South Africa and is located in the central Gauteng province- the economic hub of the country. The city has a population of roughly two million residents and has a relatively heterogeneous social and economic structure.

\section{Materials and methods}

Data

Crime data for the city of Tshwane was obtained from the former Crime Information Analysis Centre (CIAC) of the South African Police Services (SAPS) ${ }^{3}$. A total of 23 different types of crime data were obtained for the city from September 1, 2002 to August 31, 2007 (five years) ${ }^{4}$. Included in the data were the location (x, y co-ordinate), date, and time of day, as well as a unique code for each crime incident. A total of 726,700 incidents of crime were recorded by the SAPS over this time period in Tshwane. The 23 different types of crime were categorized into either violent, property or sexual crime and aggregated to the suburb spatial boundary level ( $n=353)$ and a five-year mean (2002-2007; rate per 1,000 person) calculated per suburb to minimize the impact of annual fluctuations. According to Statistics South Africa each suburb consists of between 150 - 300 households. In our study a suburb approximates a neighborhood. It is readily acknowledged that the definition of a neighborhood has created substantial debate in the literature where researchers have long 
argued that a geographical construct of place is not limited by an administratively defined boundary (see Duncan, 1957; Lefebvre, 1991). In this study neighborhoods are likewise defined as a spatial unit created by an artificial geoboundarization process. However placebased studies demand that researchers identify a set of geographical boundaries to identify a place. This is especially important in that is gives greater proficiency to researchers to communicate their findings on how place affects the individual (Siordia \& Saenz, 2013). Although the association between crime and place (or the neighborhood) is more contextual than causal, it is still nonetheless real (Davies, 2005).

All the sociodemographic variables used in this study to represent social disorganization theory were drawn from Statistics South Africa's 2001 census dataset. Four main social disorganization measures were operationalized based on the central tenets of the theory: ethnic heterogeneity, socioeconomic deprivation, family disruption, and residential mobility. The percentage of residents that are foreign born was utilized as a measure of ethnic heterogeneity. Prior operationalizations of ethic heterogeneity have used a racialized measure like the percent Black (see Ouimet, 2000; Rice \& Smith, 2002). In South Africa however the rich array of ethnic backgrounds including its four official racial groups (i.e., Black African, Colored, Asian or Indian; and White), and four main tribal groups each broken up into nine distinctive ethnic subdivisions makes such an operationalization crude and simplistic. Besides the aim of our study was to examine racial concentrations of crime so including a race-based variable in the analysis was deemed superfluous. Socioeconomic deprivation was represented by the percentage of the population that are unemployed; and by a deprivation index based on the United Nations Development Program's (2003) parameters for deprivation in each of five dimensions: type of dwelling, source of water, toilet facilities, refuse or rubbish removal, and energy or fuel for lighting, heating or cooking. The deprivation index is calculated as a simple average of the five basic services indices, with 0 indicating extreme deprivation and 1 
indicating affluence. Past approaches in Europe and North America have found unemployment and deprivation to both be among the strongest predictors of crime rates (see Cahill \& Mulligan, 2003; Andresen, 2006; McCall and Nieuwbeerta, 2007). Family disruption was represented by the percent estranged or deceased father, and the percent divorced or separated. The former variable ascertains whether the resident is aware of their father's mortality status, or whereabouts, and was intended to reflect broader family composition or rather the degree of familial structure within communities. According to social disorganization theory, an individual from a disrupted family is less likely to develop local friendship networks and a concomitant sense of connection with their neighborhood and which can lead to neighborhood disintegration and crime. Finally, two variables were included to represent residential mobility: the percentage of residents who had moved in the last five years; and the percentage of rental households. Residential mobility has traditionally been associated with a lack of social cohesion and collective efficacy (Sampson \& Groves, 1989) with the idea being that in highly mobile communities, residents are unlikely to know each other and will be less eager to notice and/or intervene in suspect situations. Previous research has largely demonstrated that communities with higher levels of residential mobility tend to experience higher levels of crime across most categories (see Andresen, 2006; Breetzke, 2010; Bernasco \& Luykx, 2003; Ceccato \& Dolmen, 2011).

\section{Descriptive analysis}

Descriptive statistics of violent, property and sexual crime were calculated for neighborhoods across the city as a whole and then in neighborhoods categorized as predominantly Black African, White, and Mixed ${ }^{5}$. The Pareto principle was then tested by examining the percentage of neighborhoods accounting for $80 \%$ of crime. Again, this was done for all 
neighborhoods in the city as well as for neighborhoods stratified by race. Finally, descriptive statistics for the independent variables used in the regression analysis are provided.

\section{Empirical analysis}

Spatial regression models were fitted to test the spatial association between violent, property, and sexual crime rates and the selected independent variables at the neighborhood level. This was done for the whole city and then in neighborhoods stratified by race. Using the Lagrange Multiplier (LM) tests (LM-Error and LM-Lag), which tests the null hypothesis of no spatial dependence against alternatives of spatial error and spatial lag dependence respectively, strong evidence of spatial autocorrelation was found. Only the LM-Lag test statistic was significant, while the LM-Error statistic was not thereby motivating for the estimation of a spatial lag model.

The general functional form of the spatial lag model is:

$$
y=p W y+X \mathrm{~B}+\varepsilon
$$

Where $y$ represents the crime rates per 1,000 population, $W y$ is the weighted mean of the local values of $y$ in neighboring areas, $p$ is the parameter, $X$ is the set of motivators, $\mathrm{B}$ is a vector of coefficients to be estimated and $\varepsilon$ is the error term. Spatial autocorrelation was modeled using a distance parameter due to the spatial structure of the data.

One final concern in the modelling process is multicollinearity. Multicollinearity makes determining the importance of any given variable difficult because the effects of the variables are confounded due to possible correlations between them. Such a situation is only problematic if a high degree of multicollinearity is present among the variables of interest. This is not the case in the current analysis as bivariate correlations examined between the independent variables indicated only two relationships exceeding 0.80 , a common threshold 
of concern (see Andresen, 2006). Analysis was performed using the GeoDa spatial statistical freeware package (http://spatial.uchicago.edu/software).

\section{Results}

\section{Descriptive}

Descriptive statistics of the categorized violent, property, and sexual crime are provided in Tables 1-3. A number of observations are worthy of mention. First, within the violent crime category, common assault accounts for more than half of all violent crime incidents reported in the city as a whole (see Table 1). Moreover, the two types of assault (common assault, and assault with intent to cause grievous bodily harm $(\mathrm{GBH})$ ) constitute roughly $88 \%$ of all violent crime recorded. Approximately 58\% of all violent crime occurs in Black African neighborhoods followed by $29 \%$ in Mixed neighborhoods and $13 \%$ in White neighborhoods. Black African neighborhoods on average experience almost four times more violent crime than White neighborhoods. The only crime type which is not most often prevalent in Black African neighborhoods is culpable homicide, which is higher in Mixed neighborhoods.

The most common types of property crimes recorded in Tshwane are theft, and household burglary (see Table 2). Collectively these two types of property crime constitute roughly $67 \%$ of all property crime recorded in Tshwane. Very interestingly, and in contrast to the violent crime category, the largest amount of property crime occurs in Mixed (44\%) and White (29\%) neighborhoods compared with Black African (27\%) neighborhoods. While both theft and burglary account for the majority of crime occurring in neighborhoods across all racial groups some interesting additional trends emerge. For example, household burglary is highest in White neighborhoods; while theft of car or motorcycle in both White and Mixed neighborhoods are on average over four times greater than in Black African neighborhoods. 
Table 1: Descriptive statistics of violent crime in Tshwane by neighborhood type (2002-2007)

\begin{tabular}{|c|c|c|c|c|c|c|c|c|c|c|c|c|}
\hline & \multicolumn{3}{|c|}{$\begin{array}{l}\text { All neighborhoods } \\
\quad(n=353)\end{array}$} & \multicolumn{3}{|c|}{$\begin{array}{c}\text { White } \\
\text { neighborhoods } \\
(n=113)\end{array}$} & \multicolumn{3}{|c|}{$\begin{array}{l}\text { Black African } \\
\text { neighborhoods } \\
\quad(n=136)\end{array}$} & \multicolumn{3}{|c|}{$\begin{array}{c}\text { Mixed } \\
\text { neighborhoods } \\
(n=104)\end{array}$} \\
\hline & $N$ & Mean & $\mathrm{SD}$ & $N$ & Mean & $\mathrm{SD}$ & $N$ & Mean & $\mathrm{SD}$ & $N$ & Mean & SD \\
\hline All violent crime & 178509 & 505.7 & 1071.7 & 22813 & 201.9 & 230.3 & 103371 & 760.1 & 1268.4 & 52325 & 503.1 & 1253.8 \\
\hline Common assault & 94342 & 267.3 & 620.4 & 15494 & 137.1 & 160.2 & 47058 & 346 & 697.4 & 31790 & 305.7 & 788.4 \\
\hline Attempted murder & 9171 & 26 & 53.9 & 1147 & 10.2 & 10.9 & 5964 & 43.9 & 74 & 2060 & 19.8 & 43.5 \\
\hline Murder & 3765 & 10.7 & 22.9 & 324 & 2.9 & 3.1 & 2562 & 18.8 & 31.6 & 879 & 8.5 & 18 \\
\hline Culpable homicide & 3038 & 8.6 & 16.7 & 644 & 5.7 & 6.3 & 1113 & 8.2 & 10.5 & 1281 & 12.3 & 27.2 \\
\hline Arson & 2570 & 7.3 & 15.5 & 237 & 2.1 & 2.7 & 1758 & 12.9 & 20.6 & 575 & 5.5 & 13.4 \\
\hline Abduction & 1522 & 4.3 & 9.6 & 212 & 1.9 & 2.5 & 788 & 5.8 & 9.5 & 522 & 5 & 13.4 \\
\hline Kidnapping & 887 & 2.5 & 6.2 & 64 & 0.6 & 1 & 625 & 4.6 & 7.1 & 198 & 1.9 & 7.4 \\
\hline Child abuse & 829 & 2.3 & 4.7 & 152 & 1.3 & 1.9 & 415 & 3.1 & 5.5 & 262 & 2.5 & 5.4 \\
\hline Public violence & 219 & 0.6 & 1.5 & 26 & 0.2 & 0.5 & 132 & 1 & 1.9 & 61 & 0.6 & 1.5 \\
\hline
\end{tabular}


Table 2: Descriptive statistics of property crime in Tshwane by neighborhood type (2002-2007)

\begin{tabular}{|c|c|c|c|c|c|c|c|c|c|c|c|c|}
\hline & \multicolumn{3}{|c|}{$\begin{array}{l}\text { All neighborhoods } \\
\quad(n=353)\end{array}$} & \multicolumn{3}{|c|}{$\begin{array}{c}\text { White } \\
\text { neighborhoods } \\
(n=113)\end{array}$} & \multicolumn{3}{|c|}{$\begin{array}{l}\text { Black African } \\
\text { neighborhoods } \\
(n=136)\end{array}$} & \multicolumn{3}{|c|}{$\begin{array}{c}\text { Mixed } \\
\text { neighborhoods } \\
(n=104)\end{array}$} \\
\hline & $N$ & Mean & SD & $N$ & Mean & SD & $N$ & Mean & SD & $N$ & Mean & SD \\
\hline All property crime & 529888 & 1501.1 & 3659.8 & 157312 & 1392.1 & 1462.1 & 140219 & 1031 & 1583.6 & 232357 & 2234.2 & 6270.3 \\
\hline Theft & 242945 & 688.2 & 1861.4 & 64009 & 566.5 & 637 & 62418 & 459 & 773.2 & 116518 & 1120.4 & 3215.9 \\
\hline Household burglary & 112125 & 317.6 & 442.4 & 43669 & 386.5 & 443.1 & 34642 & 254.7 & 387.6 & 33814 & 325.1 & 497.9 \\
\hline Theft of car or motorcycle & 52714 & 149.3 & 317.1 & 23415 & 207.2 & 218.1 & 6800 & 50 & 66.7 & 22499 & 216.3 & 514.6 \\
\hline Common robbery & 42336 & 119.9 & 461.1 & 5386 & 47.7 & 59 & 18120 & 133.2 & 233.6 & 18830 & 181.1 & 801 \\
\hline Fraud & 29422 & 83.4 & 376.3 & 8847 & 78.3 & 110.9 & 3367 & 24.8 & 49 & 17208 & 165.5 & 675.2 \\
\hline Shoplifting & 24156 & 68.4 & 356 & 5034 & 44.5 & 90.4 & 6705 & 49.3 & 143.4 & 12417 & 119.4 & 627.3 \\
\hline Burglary excluding houses & 17020 & 48.2 & 139.9 & 4323 & 38.3 & 46.6 & 4879 & 35.9 & 82.9 & 7818 & 75.2 & 233.4 \\
\hline House robbery & 6434 & 18.2 & 29.2 & 1759 & 15.6 & 21.1 & 2429 & 17.9 & 23 & 2246 & 21.6 & 41.6 \\
\hline Business robbery & 2573 & 7.3 & 16.9 & 835 & 7.4 & 9.3 & 777 & 5.7 & 11.8 & 961 & 9.2 & 26.4 \\
\hline Cash in transit heists & 163 & 0.5 & 1.2 & 35 & 0.3 & 0.8 & 82 & 0.6 & 1.3 & 46 & 0.4 & 1.4 \\
\hline
\end{tabular}


Table 3: Descriptive statistics of sexual crime in Tshwane by neighborhood type (2002-2007)

\begin{tabular}{|c|c|c|c|c|c|c|c|c|c|c|c|c|}
\hline & \multicolumn{3}{|c|}{$\begin{array}{l}\text { All neighborhoods } \\
\quad(n=353)\end{array}$} & \multicolumn{3}{|c|}{$\begin{array}{c}\text { White } \\
\text { neighborhoods } \\
(n=113)\end{array}$} & \multicolumn{3}{|c|}{$\begin{array}{l}\text { Black African } \\
\text { neighborhoods } \\
\quad(n=136)\end{array}$} & \multicolumn{3}{|c|}{$\begin{array}{c}\text { Mixed } \\
\text { neighborhoods } \\
(n=104) \\
\end{array}$} \\
\hline & $N$ & Mean & SD & $N$ & Mean & $\mathrm{SD}$ & $N$ & Mean & $\mathrm{SD}$ & $N$ & Mean & $\mathrm{SD}$ \\
\hline All sexual crime & 18303 & 51.9 & 100.8 & 1844 & 16.3 & 18.2 & 11903 & 87.5 & 130 & 4556 & 43.8 & 95.4 \\
\hline Rape & 14117 & 39.9 & 80.4 & 1071 & 9.5 & 11.2 & 9894 & 72.8 & 107.1 & 3152 & 30.3 & 66.3 \\
\hline Indecent assault & 1900 & 5.4 & 13.7 & 642 & 5.7 & 7 & 833 & 6.1 & 10.7 & 425 & 4.1 & 11.4 \\
\hline Attempted rape & 2286 & 6.5 & 11 & 131 & 1.2 & 1.5 & 1176 & 8.6 & 13.6 & 979 & 9.4 & 20.8 \\
\hline
\end{tabular}


Only three types of crime were included in the sexual crime category, these included rape, attempted rape, and indecent assault (see Table 3). Sexual crime is notoriously under-reported in South Africa. Reasons for this have been found to be related to a general distrust in the SAPS (Coetzer, 2005), fear of retaliation or intimidation by the offender (Vetten, 2014) and low conviction rates among perpetrators of sexual crime (Hirschowitz, Worku, \& Orkin, 2000), among others. It is anticipated however that this 'sample' of data does somewhat reflect the greater patterns of this type of crime occurring within the city. Roughly $65 \%$ of recorded sexual crime occurs in Black African neighborhoods compared with $25 \%$ in Mixed neighborhoods and $10 \%$ in White neighborhoods. Rape accounts for the majority of sexual crime occurring in neighborhoods across all racial groups and is almost seven times higher in Black African neighborhoods than White neighborhoods and more than two times higher than in Mixed neighborhoods. The high standard deviations relative to the totals across all crimes and across all racial groups suggests great variability in crime between neighborhoods in the city as a whole and within each racial grouping.

The results of the test of the Pareto principle is provided in Figures 2-4. The values represented on the y axis refers to the percentage of neighborhoods containing $80 \%$ of crime per crime type. The horizontal line represents the ideal-typical Pareto principle of $20 \%$.

It is immediately observable across all figures that the spatial distribution of crime in Tshwane roughly follows an 80/20 split in adherence with the Pareto principle. Within the violent crime category (see Figure 2) all ten crime types occur relatively close to the $20 \%$ line measure. In some instances, notably kidnapping and public violence, the overall distribution is even more spatially clustered in locations, with $80 \%$ of crime in these categories occurring in $18 \%$ and $17 \%$ of possible locations respectively. The most dispersed violent crime is culpable homicide followed by attempted murder. Common assault and assault GBH which collectively constitute roughly $88 \%$ of all violent crime recorded; and child abuse and public 


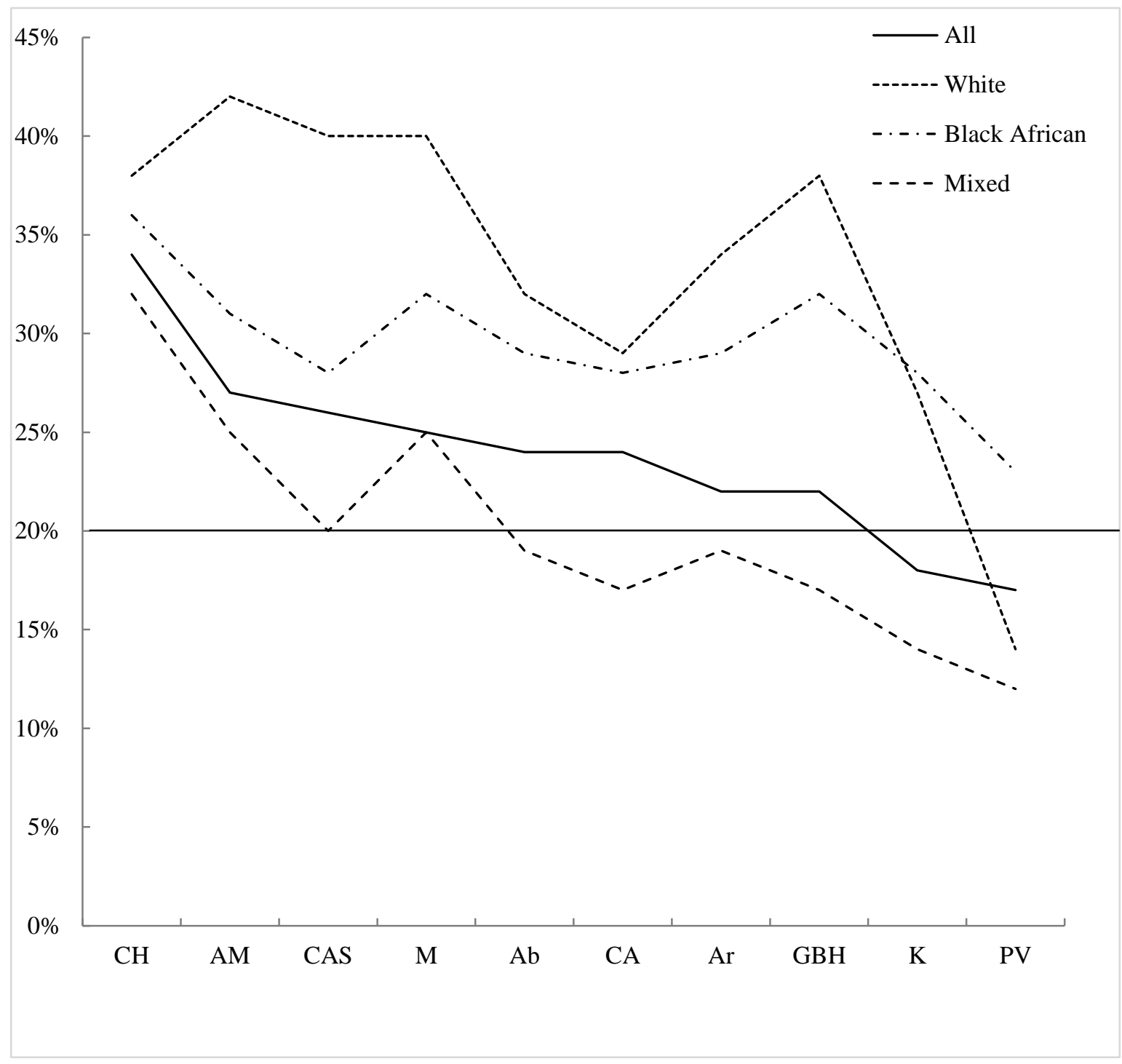

Figure 2: Application of the Pareto principle for violent crime in Tshwane

Note: CH: Culpable homicide; AM: Attempted murder; CAS: Common assault; M: Murder; Ab: Abduction; CA: Child abuse; Ar: Arson; GBH: Assault GBH; K: Kidnapping; PV: Public violence 


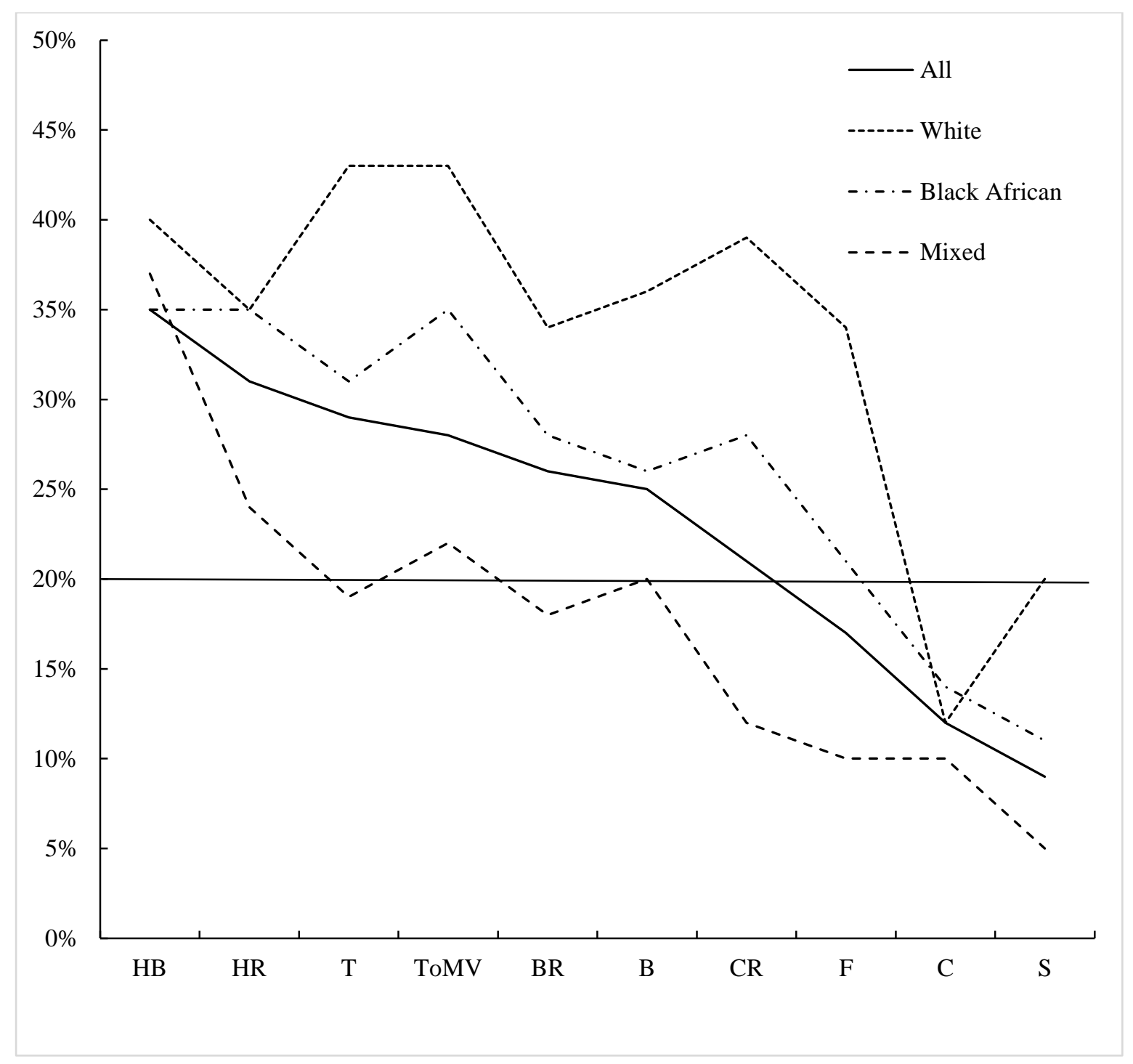

Figure 3: Application of the Pareto principle for property crime in Tshwane

Note: HB: Household burglary; HR: Household robbery; T: Theft; ToCMV: Theft of Motor Vehicle; BR: Business robbery; B: Burglary; CR: Common robbery; F: Fraud; C: Cash in transit heists; S: Shoplifting 


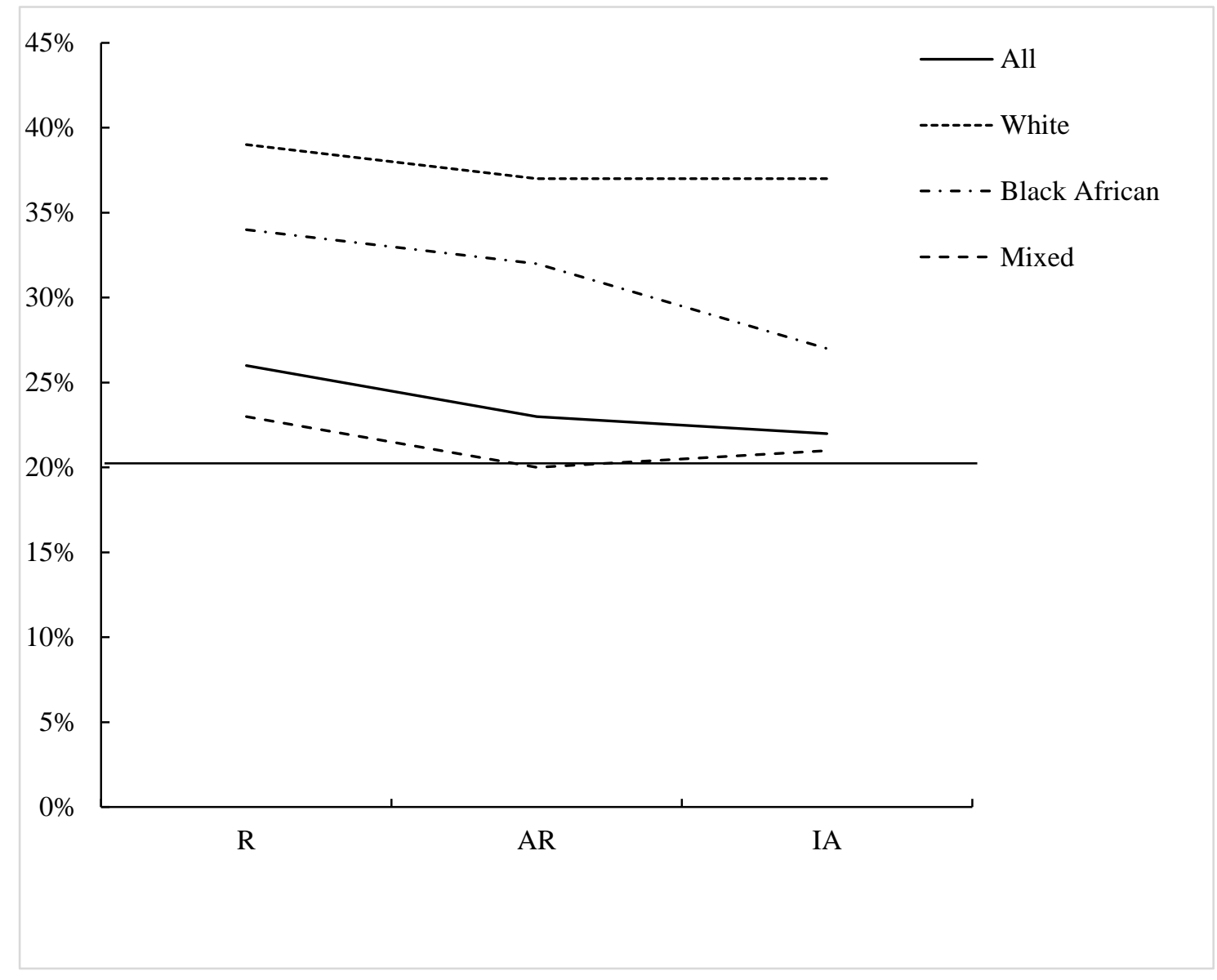

Figure 4: Application of the Pareto principle for sexual crime in Tshwane

Note: R: Rape; AR: Attempted rape; IA: Indecent assault 
violence which collectively constitute less than $1 \%$ of all violent crime both have distributions roughly adhering to the Pareto principle. Violent crime is Mixed neighborhoods most closely approximates the Pareto principle and is generally most dispersed in White neighborhoods, across all violent crime types.

Most of the ten property crime types hover around the $20 \%$ Pareto line, although overall there is greater dispersion (see Figure 3). Disturbingly house burglary was found to be the most dispersed property crime with $80 \%$ of house burglaries occurring in just over a third of neighborhoods in the city; this was followed by house robbery $(32 \%)$ and theft $(28 \%)$. Overall the most concentrated property crimes are shoplifting and cash in transit heists followed by fraud. Again, similar to the violent crime category the $80 / 20$ split is most consistent with the Mixed neighborhoods and more dispersed among White neighborhoods across almost all crime types.

Last, within the sexual crime category (see Figure 4) all three crime types lie slightly above the $20 \%$ Pareto line. Indecent assault is the most dispersed sexual crime with $80 \%$ of incidences occurring in $28 \%$ of possible locations, while attempted rate and rape are slightly more clustered. Again, the magnitude of each type of sexual crime does not appear to influence the proportions observed. In terms of race, Mixed neighborhoods again most closely approximate the Pareto line.

Finally, the descriptive statistics for the independent variables used in the regression analysis are presented in Table 4. A number of features were particularly prominent. First, the results illustrate the disrupted nature of families in Tshwane with almost 40 percent of households having an absent father, and with roughly a third of residents having moved over the past five years. Greater details emerge when the variables are stratified by race. For example, White neighborhoods are generally much more affluent than their Black African and Mixed counterparts. In fact, rather staggeringly, almost $30 \%$ of residents in Black 
Table 4: Descriptive statistics of the independent variables used in the spatial regression

\begin{tabular}{|c|c|c|c|c|c|c|c|c|c|c|c|c|c|c|c|c|}
\hline & \multicolumn{4}{|c|}{$\begin{array}{l}\text { All neighborhoods } \\
\quad(n=353)\end{array}$} & \multicolumn{4}{|c|}{$\begin{array}{c}\text { White } \\
\text { neighborhoods } \\
(n=113)\end{array}$} & \multicolumn{4}{|c|}{$\begin{array}{l}\text { Black African } \\
\text { neighborhoods } \\
(n=136)\end{array}$} & \multicolumn{4}{|c|}{$\begin{array}{c}\text { Mixed } \\
\text { neighborhoods } \\
(n=104)\end{array}$} \\
\hline & Min & Mean & Max & SD & Min & Mean & Max & SD & Min & Mean & $\operatorname{Max}$ & $\mathrm{SD}$ & Min & Mean & Max & SD \\
\hline$\%$ unemployed & 0 & 14.5 & 53 & 14.0 & 0 & 3.1 & 13.5 & 2.4 & 2.1 & 29.1 & 53 & 10.9 & 0 & 7.7 & 29.1 & 6.3 \\
\hline SDI & 0 & 0.8 & 1 & 0.3 & 0 & 0.9 & 1 & 0.1 & 0 & 0.7 & 1 & 0.3 & 0 & 0.9 & 1 & 0.2 \\
\hline$\%$ foreign born & 0 & 4.70 & 27.7 & 4.4 & 0 & 6.3 & 14.6 & 3.1 & 0 & 1.9 & 24 & 3 & 0 & 6.5 & 27.7 & 5.2 \\
\hline$\%$ moved in the last five years & 0.5 & 31.4 & 90.8 & 20.1 & 1.4 & 34.8 & 90.8 & 15.1 & 0.5 & 22.1 & 87.5 & 22.6 & 5.3 & 39.8 & 85.4 & 16 \\
\hline$\%$ renting & 0 & 23.3 & 95.6 & 21.1 & 0 & 21.3 & 69 & 10.8 & 0 & 17.5 & 95.6 & 21.7 & 0 & 33.2 & 93.7 & 24.4 \\
\hline$\%$ absent or estranged father & 15.6 & 39.2 & 99 & 8.3 & 15.6 & 41.6 & 99 & 10.8 & 23.7 & 37.5 & 51.6 & 4.8 & 15.8 & 38.9 & 64.5 & 8.4 \\
\hline$\%$ divorced or separated & 0 & 3.8 & 13.2 & 2.2 & 1.1 & 5.5 & 10.5 & 2 & 0 & 2.2 & 5.2 & 0.9 & 0.7 & 4 & 13.2 & 2 \\
\hline
\end{tabular}


African neighborhoods in Tshwane are unemployed. Also notable is the fact that there is a higher percentage of households with absent fathers in White neighborhoods compared to Black African neighborhoods. The descriptive statistics of the Mixed neighborhoods most often reflect White neighborhoods with the notable exception of unemployment which is lower in Mixed neighborhoods. Finally, the relatively large standard deviations across most variables suggest that scores are widely dispersed and vary considerably both across the city as a whole and within neighborhoods stratified by race.

\section{Analytical}

The results of the spatial regression models for the city as a whole were low with the pseudo- $R^{2}$ values ranging from 0.03 for the overall sexual model to 0.10 for the overall property model (see Tables 5-7). Results were slightly more encouraging when the models were stratified by race with results for the violent crime models ranging from 0.10 for the Black African model to 0.27 for the Mixed model; for property crime results ranged from 0.16 for the Mixed model to 0.27 for the Black African model; and finally for sexual crime scores ranged from 0.07 for the Black African model to 0.31 for the White model. It is important to note that while these overall values are relatively low this is not uncommon in spatial cross-sectional research (see de Melo et al., 2016). Moreover, the pseudo- $\mathrm{R}^{2}$ values should not be interpreted in the same manner as the adjusted $R^{2}$ values in a linear regression with the pseudo- $R^{2}$ values shown here being the correlation between the actual and predicted values of the dependent variable.

In terms of violent crime, no measures of social disorganization were found to be significant in the overall model. Three measures were found to be the primary determinants of rates of violent crime in White neighborhoods across Tshwane: percent foreign born (negatively), percent renting (positively), and the percent divorced or separated (negatively). 
Table 5: Spatial regression results for violent crime

\begin{tabular}{|c|c|c|c|c|}
\hline & $\begin{array}{c}\text { All } \\
\text { neighborhoods } \\
(n=353)\end{array}$ & $\begin{array}{c}\text { White } \\
\text { neighborhoods } \\
(n=113)\end{array}$ & $\begin{array}{l}\text { Black African } \\
\text { neighborhoods } \\
\quad(n=136)\end{array}$ & $\begin{array}{c}\text { Mixed } \\
\text { neighborhoods } \\
(n=104)\end{array}$ \\
\hline Variable & $\begin{array}{l}\text { Standardized } \\
\text { coefficient }\end{array}$ & $\begin{array}{c}\text { Standardized } \\
\text { coefficient }\end{array}$ & $\begin{array}{l}\text { Standardized } \\
\text { coefficient }\end{array}$ & $\begin{array}{l}\text { Standardized } \\
\text { coefficient }\end{array}$ \\
\hline Constant & $\begin{array}{c}0.00 \\
(0.05)\end{array}$ & $\begin{array}{l}-0.11 \\
(0.04)\end{array}$ & $\begin{array}{c}0.69 \\
(0.31)\end{array}$ & $\begin{array}{c}0.05 \\
(0.07)\end{array}$ \\
\hline Spatial dependence & $\begin{array}{l}-0.07 \\
(0.13)\end{array}$ & $\begin{array}{l}-0.05 \\
(0.11)\end{array}$ & $\begin{array}{l}-0.05 \\
(0.13)\end{array}$ & $\begin{array}{l}-0.14 \\
(0.14)\end{array}$ \\
\hline$\%$ unemployed & $\begin{array}{c}-0.10 \\
0.09\end{array}$ & $\begin{array}{c}0.03 \\
(0.03)\end{array}$ & $\begin{array}{l}-0.59 * * \\
(0.21)\end{array}$ & $\begin{array}{c}0.19 \\
(0.12)\end{array}$ \\
\hline SDI & $\begin{array}{l}-0.17 \\
(0.08)\end{array}$ & $\begin{array}{c}0.01 \\
(0.02)\end{array}$ & $\begin{array}{l}-0.25 \\
(0.15)\end{array}$ & $\begin{array}{l}-0.08 \\
(0.08)\end{array}$ \\
\hline$\%$ foreign born & $\begin{array}{l}-0.07 \\
(0.06)\end{array}$ & $\begin{array}{l}-0.02 * \\
(0.01)\end{array}$ & $\begin{array}{l}-0.09 \\
(0.21)\end{array}$ & $\begin{array}{c}0.02 \\
(0.04)\end{array}$ \\
\hline$\%$ moved in the last 5 years & $\begin{array}{c}0.12 \\
(0.06)\end{array}$ & $\begin{array}{l}-0.01 \\
(0.01)\end{array}$ & $\begin{array}{c}0.12 \\
(0.11)\end{array}$ & $\begin{array}{l}0.19 * * \\
(0.07)\end{array}$ \\
\hline$\%$ renting & $\begin{array}{c}0.02 \\
(0.06)\end{array}$ & $\begin{array}{c}0.05^{* * * *} \\
(0.01)\end{array}$ & $\begin{array}{l}-0.09 \\
(0.13)\end{array}$ & $\begin{array}{c}0.04 \\
(0.04)\end{array}$ \\
\hline$\%$ absent or estranged father & $\begin{array}{c}0.13 \\
(0.06)\end{array}$ & $\begin{array}{c}0.01 \\
(0.01)\end{array}$ & $\begin{array}{l}0.49 * \\
(0.22)\end{array}$ & $\begin{array}{c}0.22 * * * \\
(0.06)\end{array}$ \\
\hline$\%$ divorced/separated & $\begin{array}{l}-0.03 \\
(0.06)\end{array}$ & $\begin{array}{l}-0.02 * \\
(0.01)\end{array}$ & $\begin{array}{c}0.11 \\
(0.35)\end{array}$ & $\begin{array}{c}0.09 \\
(0.05)\end{array}$ \\
\hline $\begin{array}{l}\text { AIC } \\
\text { Pseudo R-squared }\end{array}$ & $\begin{array}{c}1006.42 \\
0.04\end{array}$ & $\begin{array}{c}-318.356 \\
0.26\end{array}$ & $\begin{array}{c}505.79 \\
0.10\end{array}$ & $\begin{array}{c}148.65 \\
0.27\end{array}$ \\
\hline
\end{tabular}

NOTE: $* p<0.05, * * p<0.01, * * * p<0.001$; standard errors in parenthesis 
Table 6: Spatial regression results for property crime

\begin{tabular}{|c|c|c|c|c|}
\hline & $\begin{array}{c}\text { All } \\
\text { neighborhoods } \\
(n=353)\end{array}$ & $\begin{array}{c}\text { White } \\
\text { neighborhoods } \\
(n=113)\end{array}$ & $\begin{array}{l}\text { Black African } \\
\text { neighborhoods } \\
\quad(n=136)\end{array}$ & $\begin{array}{c}\text { Mixed } \\
\text { neighborhoods } \\
(n=104)\end{array}$ \\
\hline Variable & $\begin{array}{l}\text { Standardized } \\
\text { coefficient }\end{array}$ & $\begin{array}{c}\text { Standardized } \\
\text { coefficient }\end{array}$ & $\begin{array}{l}\text { Standardized } \\
\text { coefficient }\end{array}$ & $\begin{array}{l}\text { Standardized } \\
\text { coefficient }\end{array}$ \\
\hline Constant & $\begin{array}{c}0.01 \\
(0.05)\end{array}$ & $\begin{array}{l}-0.18 \\
(0.05)\end{array}$ & $\begin{array}{c}0.64 \\
(0.22)\end{array}$ & $\begin{array}{c}0.10 \\
(0.17)\end{array}$ \\
\hline Spatial dependence & $\begin{array}{l}-0.15 \\
(0.13)\end{array}$ & $\begin{array}{c}0.14 \\
(0.12)\end{array}$ & $\begin{array}{c}0.02 \\
(0.19)\end{array}$ & $\begin{array}{c}0.02 \\
(0.14)\end{array}$ \\
\hline$\%$ unemployed & $\begin{array}{l}-0.03 \\
(0.09)\end{array}$ & $\begin{array}{c}0.03 \\
(0.03)\end{array}$ & $\begin{array}{c}-0.56 * * * \\
(0.15)\end{array}$ & $\begin{array}{c}0.44 \\
(0.29)\end{array}$ \\
\hline SDI & $\begin{array}{l}-0.08 \\
(0.07)\end{array}$ & $\begin{array}{c}0.03 \\
(0.02)\end{array}$ & $\begin{array}{l}-0.11 \\
(0.15)\end{array}$ & $\begin{array}{c}0.05 \\
(0.19)\end{array}$ \\
\hline$\%$ foreign born & $\begin{array}{c}0.06 \\
(0.06)\end{array}$ & $\begin{array}{c}0.00 \\
(0.01)\end{array}$ & $\begin{array}{l}-0.11 \\
(0.15)\end{array}$ & $\begin{array}{l}0.23^{*} \\
(0.10)\end{array}$ \\
\hline$\%$ moved in the last 5 years & $\begin{array}{c}0.25 * * * \\
(0.06)\end{array}$ & $\begin{array}{c}0.00 \\
(0.01)\end{array}$ & $\begin{array}{c}0.27 * * * \\
(0.08)\end{array}$ & $\begin{array}{l}0.36^{*} \\
(0.16)\end{array}$ \\
\hline$\%$ renting & $\begin{array}{c}0.08 \\
(0.05)\end{array}$ & $\begin{array}{c}0.09 * * * \\
(0.02)\end{array}$ & $\begin{array}{l}-0.00 \\
(0.01)\end{array}$ & $\begin{array}{c}0.07 \\
(0.09)\end{array}$ \\
\hline$\%$ absent or estranged father & $\begin{array}{l}0.16^{* *} \\
(0.06)\end{array}$ & $\begin{array}{c}0.01 \\
(0.01)\end{array}$ & $\begin{array}{c}0.73 * * * \\
(0.16)\end{array}$ & $\begin{array}{c}0.27 \\
(0.14)\end{array}$ \\
\hline$\%$ divorced/separated & $\begin{array}{l}-0.04 \\
(0.06)\end{array}$ & $\begin{array}{c}-0.03^{* *} \\
(0.01)\end{array}$ & $\begin{array}{l}-0.00 \\
(0.26)\end{array}$ & $\begin{array}{c}0.19 \\
(0.12)\end{array}$ \\
\hline $\begin{array}{l}\text { AIC } \\
\text { Pseudo R-squared }\end{array}$ & $\begin{array}{c}983.27 \\
0.10\end{array}$ & $\begin{array}{c}-218.369 \\
0.23\end{array}$ & $\begin{array}{c}414.702 \\
0.27\end{array}$ & $\begin{array}{c}328.534 \\
0.16\end{array}$ \\
\hline
\end{tabular}

NOTE: $* p<0.05, * * p<0.01, * * * p<0.001$; standard errors in parenthesis 
Table 7: Spatial regression results for sexual crime

\begin{tabular}{|c|c|c|c|c|}
\hline & $\begin{array}{c}\text { All } \\
\text { neighborhoods } \\
(n=353)\end{array}$ & $\begin{array}{c}\text { White } \\
\text { neighborhoods } \\
(n=113)\end{array}$ & $\begin{array}{l}\text { Black African } \\
\text { neighborhoods } \\
\quad(n=136)\end{array}$ & $\begin{array}{c}\text { Mixed } \\
\text { neighborhoods } \\
(n=104)\end{array}$ \\
\hline Variable & $\begin{array}{c}\text { Standardized } \\
\text { coefficient }\end{array}$ & $\begin{array}{l}\text { Standardized } \\
\text { coefficient }\end{array}$ & $\begin{array}{c}\text { Standardized } \\
\text { coefficient }\end{array}$ & $\begin{array}{c}\text { Standardized } \\
\text { coefficient }\end{array}$ \\
\hline Constant & $\begin{array}{c}0.00 \\
(0.05)\end{array}$ & $\begin{array}{l}-0.10 \\
(0.02)\end{array}$ & $\begin{array}{c}0.66 \\
(0.32)\end{array}$ & $\begin{array}{l}-0.00 \\
(0.06)\end{array}$ \\
\hline Spatial dependence & $\begin{array}{l}-0.05 \\
(0.14)\end{array}$ & $\begin{array}{c}0.03 \\
(0.08)\end{array}$ & $\begin{array}{l}-0.04 \\
(0.13)\end{array}$ & $\begin{array}{l}-0.13 \\
(0.14)\end{array}$ \\
\hline$\%$ unemployed & $\begin{array}{l}-0.13 \\
(0.09)\end{array}$ & $\begin{array}{c}0.02 \\
(0.02)\end{array}$ & $\begin{array}{l}-0.57 * * \\
(0.21)\end{array}$ & $\begin{array}{l}0.05 \\
(0.11)\end{array}$ \\
\hline SDI & $\begin{array}{l}-0.17 \\
(0.08)\end{array}$ & $\begin{array}{l}-0.00 \\
(0.01)\end{array}$ & $\begin{array}{l}-0.23 \\
(0.15)\end{array}$ & $\begin{array}{l}-0.10 \\
(0.07)\end{array}$ \\
\hline$\%$ foreign born & $\begin{array}{l}-0.08 \\
(0.06)\end{array}$ & $\begin{array}{l}-0.01 \\
(0.00)\end{array}$ & $\begin{array}{l}-0.08 \\
(0.21)\end{array}$ & $\begin{array}{l}-0.02 \\
(0.04)\end{array}$ \\
\hline$\%$ moved in the last 5 years & $\begin{array}{c}0.07 \\
(0.06)\end{array}$ & $\begin{array}{l}-0.01 \\
(0.00)\end{array}$ & $\begin{array}{c}0.07 \\
(0.11)\end{array}$ & $\begin{array}{l}0.12^{*} \\
(0.06)\end{array}$ \\
\hline$\%$ renting & $\begin{array}{c}0.00 \\
(0.06)\end{array}$ & $\begin{array}{c}0.03^{* * *} \\
(0.01)\end{array}$ & $\begin{array}{l}-0.11 \\
(0.14)\end{array}$ & $\begin{array}{c}0.03 \\
(0.04)\end{array}$ \\
\hline$\%$ absent or estranged father & $\begin{array}{c}0.07 \\
(0.06)\end{array}$ & $\begin{array}{l}-0.00 \\
(0.00)\end{array}$ & $\begin{array}{c}0.37 \\
(0.23)\end{array}$ & $\begin{array}{l}0.16^{* *} \\
(0.05)\end{array}$ \\
\hline$\%$ divorced/separated & $\begin{array}{l}-0.02 \\
(0.06)\end{array}$ & $\begin{array}{l}-0.00 \\
(0.00)\end{array}$ & $\begin{array}{c}0.11 \\
(0.36)\end{array}$ & $\begin{array}{c}0.08 \\
(0.05)\end{array}$ \\
\hline $\begin{array}{l}\text { AIC } \\
\text { Pseudo R-squared }\end{array}$ & $\begin{array}{c}1010.55 \\
0.03\end{array}$ & $\begin{array}{c}-453.868 \\
0.31\end{array}$ & $\begin{array}{c}513.46 \\
0.07\end{array}$ & $\begin{array}{c}117.92 \\
0.23\end{array}$ \\
\hline
\end{tabular}

NOTE: $* p<0.05, * * p<0.01, * * * p<0.001$; standard errors in parenthesis 
Notably, two different measures were significant for Black African neighborhoods: percent unemployed (negatively), and the percent father absent or estranged (positively) while in Mixed neighborhoods the percent moved in the last five years (positively) and the percent father absent or estranged (positively) were found to be significant.

In terms of property crime, the percent moved in the last five years (positively) and the percent father absent or estranged (positively) were found to be significant in the overall model. Again, the causes of crime were found to be different in neighborhoods stratified by race with the percent renting (positively) and the percent father absent or estranged (negatively) significant in White neighborhoods while the percent unemployed (negatively), the percent who moved in the last five years (positively), and the percent father absent or estranged (positively) significant in Black African neighborhoods. There was some similarity with the Black African neighborhoods with Mixed neighborhoods with both neighborhoods exhibiting a positive significant effect for the percentage moved in the last five years.

Similar to the violent crime model, no measures of social disorganization were found to be significant in the overall sexual crime model. Only the percent renting (positively) was found to be a significant predictor for sexual crime in White neighborhoods while only the percent unemployed (negatively) was significant in the Black African neighborhoods. The percent moved in the last five years (positively) and the percent father absent or estranged (positively) were the only significant predictors of sexual crime in Mixed neighborhoods.

\section{Discussion}

In terms of space, there is a general perception in South Africa that crime is ubiquitous (see Gwala, 2007; Rautenbach, 2013; Olivier, 2014). The descriptive results of this work largely contradict these sentiments with most crime in Tshwane spatially concentrated in a relatively low number of neighborhoods. These findings reinforce the spatially skewed distributions of 
crime commonly experienced in countries outside the US including Bangladesh (Dewan, Haider \& Amin, 2013); Ghana (Appiahene-Gyamfi, 2002); Israel (Weisburd \& Amram, 2014); China (Liu, Song, \& Xiu, 2016); and New Zealand (Breetzke, 2013). Moreover, the Pareto principle was largely affirmed in a South African context with most of the 23 categories of crime roughly approximating the 80/20 split. Interestingly, the Pareto principle was also found to apply across neighborhoods stratified by race. That is, crime occurring exclusively in Black, White and Mixed neighborhoods also adhered to the 80/20 split. At least in this study, the central tenet of this well-utilized crime analysis technique broadly holds true.

In terms of race, the results we obtained were not as expected. Crime across all three broad categories was found to most often occur in Mixed neighborhoods ( $n=40 \%$ ), followed by Black African neighborhoods $(n=35 \%)$ and White neighborhoods $(n=25 \%)$. One possible explanation for the concentration of crime in Mixed neighborhoods rather than Black neighborhoods as would be expected under the premise of social disorganization theory could be related to the inequitable distribution of police resources. The SAPS currently employ a Theoretical Resource Requirement formula to determine police resource allocation for each of its 1143 police stations. The formula has been criticized for being too complex and unwieldy (Redpath \& Nagia-Luddy, 2015) resulting in the most resource-stricken police stations being located primarily in Black neighborhoods. O'Regan (2014) likens the list of under-resourced stations in the country to an 'apartheid-list' as they mimic the under-policed former township areas of the previous apartheid government. As a result the under-reporting of crime, particularly in Black neighborhoods, cannot be underestimated and may be affect the descriptive and analytical results. The full impact of which is difficult, if not impossible, to ascertain. 
So, what are the primary determinants of crime in space by race in Tshwane? The regression analysis attempted to answer this question with results indicating much variability in the causes of crime across racial groups. For example, in White neighborhoods mobility appears to be the primary determinant of crime with the percentage renting being the only variable positively and significantly associated with all three types of crime whereas in Black African neighborhoods the percentage unemployed was the only variable negatively and significantly associated with all types of crime. Finally, similar to White neighborhoods, mobility seems to be a key driver of crime in Mixed neighborhoods with the percentage of residents that moved in the last five years being the only variable positively and significantly associated with all three types of crime. The finding that different factors are associated with crime in neighborhoods stratified by race in South Africa is noteworthy. Given the socio-spatial history of cities within the country it is perhaps understandable that different tenets of the social disorganization theory would apply to different racial groups.

There were however some variables which crossed the racial divide with neighborhoods with a high percentage of households with estranged or absent fathers being positively associated with violent and property crime in Black African neighborhoods as well as with violent and sexual crime in Mixed neighborhoods. Likewise, the percentage moved was positively associated with property crime in Black African neighborhoods and all three types of crime in Mixed neighborhoods.

The results of the regression analysis lie in stark contrast with various international and local explanations for the spatial concentration of crime by race (see Anderson, 1999; Peterson \& Krivo, 2010; Sampson, 1987; Shihadeh \& Ousey, 1998). In these studies researchers routinely blame inherent social inequalities borne out of racial-spatial segregation and economic discrimination for disproportionate crime distributions by race. Similar to the US, it is 'Black' neighborhoods in South Africa that experience 
disproportionate concentrated disadvantage. Indeed, there is little doubt that Black African neighborhoods are still severely deprived in post-apartheid South Africa. The country has the highest rates of inequality in the world driven almost exclusively along racial lines (Seekings \& Natrass, 2006); and, rather disturbingly, there is increasing evidence that this inequality is in fact increasing (Bhorat \& van der Westhuizen, 2012). Countrywide, more than $45 \%$ of Black Africans are unemployed compared with only $5 \%$ of Whites; White families earn on average more than six times what Black African families earn; and although Whites are only $10 \%$ of the economically active population but occupy more than $60 \%$ of the top management positions (Mngxitama, 2015). Yet despite these worrying statistics we found that unemployment - a key indicator of economic disadvantage - was significantly and negatively related to all three types of crime. While this rather surprising finding lies in contrast to the tenets proposed by social disorganization theory it is not necessarily uncommon in the literature with researchers attributing an observed negative association between crime and unemployment to the complicated nature of this relationship (Kelly, 2000), as well as the fact that the neighborhood unit of analysis most often does not adequately capture the relevant job market (Demombynes \& Özler, 2005). Another possible and more pertinent explanation for this finding could however be found in our earlier descriptive results. These results found that crime across all categories is spatially clustered within Black African neighborhoods. The fact that crime is spatial skewed within Black African neighborhoods suggests that concentrated disadvantage - whilst disproportionately high in Black African neighborhoods - may not necessarily affect all residents the same. Both violent and sexual crime were found to most often occur in Black African neighborhoods but the Pareto principle still broadly applied within these communities. If it is concentrated disadvantage and/or economic inequalities driving violent and sexual crime in these communities, as most local and international literature suggests, it could be that 
some Black neighborhoods have either improved socio-economically and/or there are other factors within these disadvantaged communities that drive resilience to criminality. That is, despite their disadvantageous settings (i.e., high unemployment), certain Black African neighborhoods are resilient to crime. There is some evidence that cultural and/or other built neighborhood level factors can make residents of deprived neighborhoods resilience to the lure of crime (see Breetzke \& Pearson, 2015). According to the researchers factors such as access to healthcare facilities, community centres and leisure spaces have been found to play a role in this regard. Of course, individual and family circumstances can also overcome the adverse effects of concentrated poverty but these can paradoxically also leave a family more vulnerable to criminal elements.

The finding that mobility is a key determinant of crime in White and Mixed neighborhoods is supported by social disorganization theory and could speak to the difficulties South Africa has experienced in building a non-racial, non-discriminate society. Whilst desegregation has certainly occurred, South Africa has struggled to engender true racial and spatial integration (see Bwalya \& Seethal, 2016; Hamann \& Horn, 2015). One glaring example of this is the process of 'resegregation' identified by Donaldson and Kotze (2006). The researchers found that while a number of neighborhoods in post-apartheid South Africa have become more racially mixed others have 'resegregated' and have gone through a cycle of becoming more mixed racially to becoming completely Black African largely due to White flight. Moreover, the increased fortification of neighborhoods in the country has impacted negatively on neighbourhood interactions between residents of different racial groups and has insulated 'fortified' residents from contact with people deemed to be 'out of place' in the suburb (Cronje \& Spocter, 2016). The positive spatial association between mobility and crime in White and Mixed neighborhoods coupled with the disproportionate 
amount of property crime in these neighborhoods could be an indication of the lack of assimilation that has occurred between the divergent racial groups in the country.

Of course, the perpetrators of these crimes are unknown so the explanations provided above are based on the assumption that offenders commit crime in the neighborhoods in which they reside. While there is some international evidence to support this (see Bernasco, 2006; Costello \& Wiles, 2001; Snook, 2004), none has been forthcoming from South Africa.

Race has, rather predictably, also played a central role in how crime in the country is rationalized and explained. Most often the racial and concomitant spatial inequalities, borne out of repressively enforced apartheid-era segregationist policies, have been used to explain crime in post-apartheid South Africa (see Breetzke, 2012) although a more sinister racial stigma is attached to its spatial distribution guided by the popular notion that crime disproportionately affects the minority White population (see Afriforum, 2009; Myburgh, 2009). The results of this research do no support this notion but rather indicate that the central tenets of the social disorganization theory apply equally, although not uniformly, in understanding crime distributions across neighborhoods stratified by race.

\section{Limitations}

There are a number of limitations which are acknowledged in this paper. First, is the underreporting of crime. The analysis that was undertaken in this study was done using data recorded by the SAPS. Using police data to measure crime has well-known limitations, particularly in South Africa (see Breetzke, 2006; Herbert \& Harries, 1986). Despite this however previous research has shown that using official police data usually produces results consistent with victimization surveys (see Ceccato \& Dolmen, 2011; McDowall \& Loftin, 1992). Whilst request for police service data may provide a better measure of crime activity over this period this information is currently unavailable in the country. In any event, official 
records from the SAPS represent the only official and spatially replete crime dataset available in the country. Second, is the fact that the results of the study are applicable to the city at the time the data was captured (i.e., 2002-2007). No doubt Tshwane has experienced significant urban change in the period post-2007. Unfortunately more recent crime data is currently unavailable in the country as an unofficial moratorium has been placed on the dissemination of address-level crime data. A previous official moratorium on the release of crime statistics was in taken in July 2000 and lifted in July 2001 amid some uncertainty regarding what methodological changes had actually been made to the statistics generation process (Schönteich, 2002). The failure to disseminate crime data in the country is frustrating as it greatly hinders the ability of countries like South Africa to make a meaningful and vital contribution to current urban criminological theory and discourse. Should updated crime data be available to us in the future we would aim to determine the longevity of these patterns observed although previous international research has however shown that urban crime concentrations generally remain stable over a considerable period of time (see Weisburd et al., 2012). Third, we acknowledge that certain types of crime can only be committed in certain locations; for example, shop-lifting (property crime) can only be located in neighborhoods with shops; similarly business robberies can only be located in neighborhoods with businesses. This has the potential to distort the descriptive findings made. In a similar vein, the at-risk population, nor the physical size of neighborhoods were taken into account. It could be, for example, that one neighborhood is consistently ranked as being the most crime-ridden simply because it is the largest in area, and/or has the highest population. These concerns have validity however much of the appeal of the Pareto principle in crime analysis lies in its simplicity. The principle is not analytical but is a purely descriptive measure which allows users to look more broadly at where repeat offending is taking place. By identifying the small proportion of neighborhoods where a large amount of criminal activity is 
concentrated allows police to better direct crime prevention efforts. Incidentally, despite these legitimate concerns, the central tenets of the Pareto principle still held true across almost all 23 crime types both across the city as a whole and across neighborhoods stratified by race. Finally, the study is context- and time-specific. In terms of the former, it could be that crime distributions in other cities in South Africa exhibit different patterns that may conform less to the Pareto principle than displayed here or that the empirical causes of crime in neighborhoods stratified by race are different in another context. In terms of the latter, the results presented here are applicable to a specific point in time in Tshwane. Both the crime and census data reflect the early 2000s and the results are applicable to that period. While the socio-demographic transformation of South African cities from democracy to the present period has been described slow and sluggish (see African Development Bank, 2016) it is possible that some significant associations found in this study may have changed. Future research should aim to replicate this type of research in cities in other countries and/or within South Africa that are distant and distinct from Tshwane and using more recent data.

\section{Conclusion}

In their thorough review of the crime-race literature Peterson and Krivo (2005) outlined five directions that scholars should follow in order to broaden knowledge on this important field in urban criminology. One key suggestion was for future research examining the crime-race linkage to take place in contexts outside the US. Drawing comparisons to other racially and ethnically diverse societies would, according to the researchers, go a long way toward revealing the patterning and etiological complexity that characterizes racial and ethnic inequalities in crime. We have taken up the challenge of Peterson and Krivo and made some progress in understanding the race-crime linkage in a country synonymous with crime and race. In doing so, we believe that we have made a number of valuable contributions. First, 
crime does spatially concentrate in segregated and marginalized communities in contexts outside the US. However the South African context differs from the US in two important ways: first, US studies of this nature are characteristically based on the segregation of minorities, for instance African Americans or Hispanics. In a South African context, it is the majority Black African population (currently over $85 \%$ of the population) that were previously legally segregated from the minority; and are still currently segregated. Second, residential racial segregation in the US has predominantly been 'voluntary' insofar as the segregation was not legislatively enforced. In contrast, the South African context is characterized by the historical legal segregation and marginalization of certain majority groups. Regardless of these differences we have however found that crime does still concentrate in these communities. Second, crime is spatially concentrated within neighborhoods stratified by race. We found that not only is crime spatially concentrated in Black African and Mixed neighborhoods but it is also spatially skewed within these communities. That is, crime does not uniformly occur across segregated and marginalized communities. This poses serious questions to the notion that racial and ethnic inequalities in crime can be attributed solely to disempowerment, inequality, marginalization, and concentrated disadvantage. Peterson and Krivo (2010) demonstrate how residential segregation creates and maintains inequality in neighborhood crime rates throughout the US. Our research has shown that desegregation may also have a role to play in explaining racial and ethnic inequalities in crime. Finally, both the Pareto principle and social disorganization theory have some applicability in a South African context. Whilst exact percentages did vary roughly $80 \%$ of crime across almost all categories in Tshwane was found to occur in roughly $20 \%$ of potential locations while certain main tenets of the social disorganization theory were found to be significant in the models. 
Recently leading environmental criminologists have argued that a turning point in the developmental career of criminology is warranted that is grounded in the knowledge that place matters (see Weisburd, Eck, Braga, Telep, et al., 2016). In this study we have found that urban geography matters in South Africa in terms of crime and its distribution by race. In doing so we believe that we have contributed to the existing and well-established theories, and hypotheses currently espoused by mainly 'Western' criminologists investigating this important criminological area of interest.

\section{Notes}

1. The South African population is still officially classified into racial groups. Black Africans represent the descendants of western and central African populations. The 'White' population group represent the descendants of mainly Western and Eastern European populations. The 'Indian' population group represent the descendants of south Asian populations. The 'Colored' group comprise a mixed population including the descendants of the indigenous Khoisan population, imported Malay slaves, and people born out of mixed-race relations. The collective term 'Black' from this point onwards refers to the Black African population group only.

2. As a result of the data available to us the pre-2011 municipal boundary for Tshwane was used in this study. In May 2011, the boundary for the city of Tshwane expanded to incorporate the Metsweding District Municipality to the east of the city.

3. Now known as the Crime Research and Statistics component of Crime Intelligence at the SAPS.

4. The definitions of the crime types can be found at SAPS (2014).

5. Whereas other researchers (see Krivo \& Peterson., 1996; McNulty, 2001) typically categorize census areas by race based on a $70 \%$ dominance, the structure of South African society allowed an even more stringent cut-off to be made (i.e., 80\%) whilst still maintaining enough neighborhoods in each category to conduct race-specific crime counts and percentages. Mixed neighborhoods were neighborhoods which did not fit into either the $80 \%$ Black African or $80 \%$ White category. 


\section{References}

African Development Bank. (2016). African economic outlook 2016: Sustainable cities and structural transformation. African Development Bank, Organisation for Economic Cooperation and Development, United Nations Development Programme.

Afriforum. (2009). Statement on Politicsweb: Afriforum seeks to intervene in Canada asylum case. Retrieved on March 17, 2017 from http://www.politicsweb.co.za/politicsweb/view/politicsweb/en/page71619?oid=142486 $\& s n=$ Marketingweb+detail.

Altbeker, Anthony. (2007). A country at war with itself: South Africa's crisis of crime. Johannesburg: Jonathan Ball.

Anderson, Elijah. (1999). Code of the street: Decency, violence, and the moral life of the inner city. New York: Norton.

Andresen, Martin A. (2006). A spatial analysis of crime in Vancouver, British Columbia: A synthesis of social disorganization and routine activity theory. Canadian Geographer, 50(4), 487-502.

Appiahene-Gyamfi, Joseph. (2002). An analyses of the broad crime trends and patterns in Ghana. Journal of Criminal Justice, 30(3), 229-243.

Boyle, Douglas J, \& Hassett-Walker, Constance. (2008). Individual-level and socio-structural characteristics of violence: An emergency department study. Journal of Interpersonal Violence, 23(8), 1011-1026.

Brantingham, Paul J, \& Brantingham, Patricia L. (1991). Environmental criminology $2^{\text {nd }}$ ed. Prospect Heights, IL: Waveland Press.

Berg, Julie, \& Schärf. Wilfred. (2004). Crime statistics in South Africa 1994-2003. South African Journal of Criminal Justice, 17(1), 57-78.

Bernasco, Wim. (2006). Co-offending and the choice of target areas in burglary. Journal of Investigative Psychology and Offender Profiling, 3(3), 139-55. 
Blackmore, F. L. E. (2003). A panel data analysis of crime in South Africa. South African Journal of Economic and Management Sciences, 6(3), 439-458.

Bhorat, Haroon, \& van der Westhuizen, Carlene. (2012). Poverty and inequality and the nature of economic growth in South Africa. Retrieved 17 March, 2017 from http://www.humanities.uct.ac.za/sites/default/files/image_tool/images/36/DPRU\%20W P12-151.pdf

Brearley, Harrington C. (1932). Homicide in the United States. Chapel Hill: University of North Carolina Press.

Breetzke, Gregory D. (2006). Geographical Information Systems (GIS) and policing in South Africa: A review, Policing: An International Journal of Policing Strategies and Management, 29(4), 723-740.

Breetzke, Gregory D. (2010). Modeling violent crime rates: A test of social disorganization in the city of Tshwane, South Africa. Journal of Criminal Justice, 38, 446-452.

Breetzke, Gregory D. (2012). Understanding the nature of crime in post-apartheid South Africa. Social Identities: Journal for the Study of Race, Nation, and Culture, 18(3), 117.

Breetzke, Gregory D. (2013). Using Crime Prevention through Environmental Design (CPTED) principles to inform the Christchurch Central City rebuild. Research report written for the New Zealand Ministry of Justice.

Breetzke, Gregory D, \& Horn, Andre C. (2006). Crossing the racial divide: A spatialecological perspective of offenders in the City of Tshwane Metropolitan Municipality, South Africa, GeoJournal, 67(3), 181-194.

Breetzke, Gregory D., Landman, Karina., \& Cohn, Ellen G. (2014). Is it safer behind the gates? Crime and gated communities in South Africa, Journal of Housing and the Built Environment, 29(1), 123-129. 
Breetzke, Gregory D, \& Pearson, Amber L. (2015). Socially disorganized yet safe:

Understanding resilience to crime in neighborhoods in New Zealand. Journal of Criminal Justice, 43, 444-452.

Brown, Kay V. (2001). The determinants of crime in South Africa. The South Africa Journal of Economics, 69, 269-299.

Bwalya, John, \& Seethal, Cecil. (2016). Neighbourhood context and social cohesion in Southernwood, East London, South Africa. Urban Studies, 53(1), 40-56.

Cahill, Megan E, \& Mulligan, Gordon F. (2003). The determinants of crime in Tucson, Arizona. Urban Geography, 24(7), 582-610.

Ceccato, Vania, \& Dolmen, Lars. (2011). Crime in rural Sweden. Applied Geography, 31(1), 119-135.

Chikane, Frank. (1986). Children in turmoil: The effects of unrest on township children. In S. Burman and P. Reynolds (Eds.), Growing up in a divided society (pp. 333-344). Johannesburg: Ravan Press.

Cohen, Lawrence E, \& Felson, Marcus. (1979). Social change and crime rate trends: a routine activity approach. American Sociological Review, 44(4), 588-608.

Coetzer, Pieter. (2005). Rape in contemporary South Africa - more vexing and viscous than ever. Journal for Contemporary History, 30(3), 169-182.

Cornish, Derek, \& Clarke, Ron V. (1986). The reasoning criminal. New York: SpringerVerlag.

Costello, Andrew, \& Wiles, Paul. (2001). GIS and the journey to crime: An analysis of patterns in South Yorkshire. In A. Hirschfield and K. Bowers, (Eds.), Mapping and analysing crime data: Lessons from research and practice, (pp. 27-60). London: Taylor \& Francis. 
Cronje, Christian J, \& Spocter, Manfred. (2016). Open-plan suburb to fortified suburb: home fortification in Soneike, Cape Town, South Africa. Journal of Housing and the Built Environment, 1-20.

Crutchfield, Robert D. (1995). Ethnicity, labor markets, and crime. In D. F. Hawkins (Ed.), Ethnicity, race, and crime: Perspectives across time and place (pp. 194-211). Albany: SUNY Press.

Curtis, Lynn A. (1975). Violence, race, and culture. Lexington, MA: Lexington Books.

Davies, Wayne K D. (2005). The social construction of urban crime variations. In Y. Murayama and G. du Plessis, (Eds.), Cities in a global perspective, (pp. 232-350). Rikkyo, Japan: College of Tourism/International Geographical Union, Urban Commission.

Davies, Toby, \& Johnson, Shane. (2015). Examining the relationship between road structure and burglary risk via quantitative network analysis. Journal of Quantitative Criminology, 31(3), 481-507.

De Melo, Silas N., Andresen, Martin A., \& Matias, Lindon F. (2016). Geography of crime in a Brazilian context: an application of social disorganization theory, Urban Geography, DOI: $10.1080 / 02723638.2016 .1255920$.

Demombynes, Gabriel, \& Özler, Berk. (2005). Crime and local inequality in South Africa. Journal of Development Economics, 76(2), 265-292.

Dewan, Ashraf M., Haider, Rafiqul, \& Amin, Ruhul. (2013). Exploring crime statistics. In A. M. Dewan and R. Corner (Eds.), Dhaka megacity: Geospatial perspectives on urbanisation, environment and health (pp.257-282). The Netherlands: Springer. 
Donaldson, Ronnie, \& Kotze, Nico. (2006). Residential desegregation dynamics in the South African city of Polokwane. Tijdschrift voor Economische en Sociale Geografie, 97(5), $567-582$.

Duncan, Otis D. (1957). The measurement of population distribution. Population Studies: A Journal of Demography, 11(1), 27-45.

Elder, Glen S. (2003). Malevolent traditions: Hostel violence and the procreational geography of apartheid. Journal of Southern African Studies, 29(4), 921-935.

Emmett, Tony. (2003). Social disorganization, social capital and violence prevention in South Africa. African Safety Promotion Journal, 1, 4-18.

Gwala, Blessed. (2007). Debate on the democratic alliance motion. Retrieved January 12, 2017 from: http://archive.ifp.org.za/Speeches/070607bsp.htm.

Harrison, Philip, \& Todes, Alison. (2015). Spatial transformations in a "loosening state": South Africa in a comparative perspective. Geoforum, 61, 148-162.

Hamann, Christian, \& Horn, Andre C. (2015). Continuity or discontinuity? Evaluating the changing socio-spatial structure of the city of Tshwane, South Africa. Urban Forum, $26,39-57$.

Herbert, David T., \& Harries, Keith D. (1986). Area-based policies for crime prevention. Applied Geography, 6, 281-295.

Hirschowitz, Ros, Worku, Seble, \& Orkin, Mark. (2000). Quantitative research findings on rape in South Africa. Pretoria: Statistics South Africa.

Ingram, Matthew C., \& da Costa, Marcelo M. (2015). Geographies of violence: A spatial analysis of five types of homicide in Brazil's municipalities. Working Paper of the Helen Kellogg Institute for International Studies, 405, 1-65.

Jürgens, Ulrich, \& Donaldson, Ronnie. (2012). A review of literature on transformation processes in South African townships, Urban Forum, 23(2), 153-163. 
Kelly, Morgan. (2000). Inequality and crime. The Review of Economics and Statistics, 82(4), $530-539$.

Krivo, Lauren J., \& Peterson, Ruth D. (1996). Extremely disadvantaged neighborhoods and urban crime. Social Forces, 75(2), 619-50.

Krivo, Lauren J., \& Peterson, Ruth D. (2000). The structural context of homicide:

Accounting for racial differences in process. American Sociological Review, 65(4), $547-59$.

Kubrin, Charis E., \& Weitzer, Ronald. (2003). New directions in social disorganization theory. Journal of Research in Crime and Delinquency, 40(4), 374-402.

Kynoch, Gary. (2005). Crime, conflict and politics in transition-era South Africa. African Affairs, 104(416), 493-514.

Lefebvre, Henri. (1991). The production of space. United Kingdom: Blackwell.

Liu, Daqian., Song, Wei., \& Xiu, Chunliang. (2016). Spatial patterns of violent crime and neighborhoods characteristics in Changchun, China. Australian and New Zealand Journal of Criminology, 49(1), 53-72.

O'Regan, Kate. (2014). O’Regan compares distribution of police resources to apartheid. Retrieved November 09, 2017 from: https://www.groundup.org.za/article/oe28099regan-compares-distribution-policeresources-apartheid_1769/.

Mabin, Alan. (2005). Suburbanisation, segregation and government of territorial transformations. Transformation, 56, 41-64.

Maree, Alice. (2003). Criminogenic risk factors for youth offending. In C. Bezuidenhout and S. Joubert (Eds.), Child and youth misbehaviour in South Africa: A holistic view (pp. 51-79). Pretoria: Van Schaiks. 
Martinez, Ramiro Jr. (2002). Latino homicide: Immigration, violence and community. New York: Routledge.

McCall, Patricia., \& Nieuwbeerta, Paul. (2007). Structural covariates of homicide rates: A European city cross-national comparative analysis. Homicide Studies, 11, 167-188. McDowall, David, \& Loftin, Colin. (1992). Comparing the UCR and NCS over time. Criminology, 30(1), 125-132.

McNulty, Thomas L. (2001). Assessing the race-violence relationship at the macro level: The assumption of racial invariance and the problem of restricted distributions. Criminology, 39(2), 467-90

Merton, Robert K. (1938). Social structure and anomie. American Sociological Review, 3(5), $672-782$.

Mngxitama, Andile. (2015). Black first! - land first! A revolutionary call. Retrieved 31 March, 2017 from: http://www.news24.com/SouthAfrica/News/Black-First-Land-FirstA-revolutionary-Call-20150813

Morenoff, Jeffrey D., Sampson, Robert J., \& Raudenbush, Stephen. (2001). Neighborhood inequality, collective efficacy, and the spatial dynamics of urban violence. Criminology, 39(3), 517-560.

Myburgh, James. (2009). Did 142 academics \& others get it wrong on crime? Retrieved 31 March, 2017 from http://www.politicsweb.co.za/politicsweb/view/politicsweb/en/page71619?oid=143475 $\& s n=$ Detail.

Olivier, Bert. (2014). Crime: There is something rotten in the state of South Africa. Retrieved 31 March, 2017 from http://thoughtleader.co.za/bertolivier/2014/10/27/crime-there-issomething-rotten-in-the-state-of-south-africa/. 
Ouimet, Marc. (2000). Aggregation bias in ecological research: How social disorganization and criminal opportunities shape the spatial distribution of juvenile delinquency in Montreal. Canadian Journal of Criminology, 42, 135-156.

Peterson, Ruth D., \& Krivo, Lauren J. (1993). Racial segregation and urban black homicide. Social Forces, 71(4), 1001-1026.

Peterson, Ruth D., \& Krivo, Lauren J. (2005). Macrostructural analyses of race, ethnicity, and violent crime: Recent lessons and new directions for research. Annual Review of Sociology, 31, 331-56.

Peterson, Ruth D., \& Krivo, Lauren J. (2010). Divergent social worlds: Neighborhood crime and the racial-spatial divide. New York: Russell Sage Foundation.

Rautenbach, Anneke. (2013). Crime fiction in South Africa: The history, the hype and the "genre snob" debate. Retrieved 10 February, 2017 from http://www.litnet.co.za/crimefiction-in-south-africa-the-history-the-hype-and-the-genre-snob-debate/

Redpath, Jean., \& Nagia-Luddy, Fairouz. (2015). Unconscious and irrational human resource allocation. SA Crime Quarterly, 53, 15-26.

Rex, Ralph., Campbell, Malene., \& Visser, Gustav. (2014). The on-going desegregation of residential property ownership in South Africa: The case of Bloemfontein. Urbani Izziv, 25, S5-S23.

Rice, Kennon J., \& Smith, William R. (2002). Socio-ecological models of automotive theft: Integrating routine activity and social disorganization approaches. Journal of Research in Crime and Delinquency, 39(3), 304-336.

Sampson, Robert J. (1987). Urban black violence: The effect of male joblessness and family disruption. American Journal of Sociology, 93(2), 348-82.

Sampson, Robert J., \& Groves, W. Byron. (1989). Community structure and crime: Testing social-disorganization theory. American Journal of Sociology, 94, 774-802. 
Shaw, Clifford, \& McKay, Henry. (1942). Juvenile delinquency and urban areas. Chicago: University of Chicago Press.

Schönteich, Martin. (2002). 2001 crime trends: A turning point? SA Crime Quarterly, 1, 1-7. Schwabe, Craig A., \& Schurink, Willem J. (2000). A classification of police stations in South Africa: Towards a better understanding of crime. Unpublished research report for the South African Department of Arts, Culture, Science and Technology (DACST), Pretoria.

Seekings, Jeremy, \& Nattrass, Nicoli. (2006). Class, race and inequality in South Africa. Connecticut: Yale University Press.

Shihadeh, Edward S., \& Ousey, Graham C. (1998). Industrial restructuring and violence: The link between entry-level jobs, economic deprivation, and black and white homicide. Social Forces, 77(1), 185-206.

Siegel, Larry J. (2001). Criminology: Theories, patterns and typologies ( $7^{\text {th }}$ Ed.). Belmont, CA: Wadsworth.

Siordia, Carlos., \& Saenz, Joseph. (2013). What is a "neighborhood"? Definition in studies about depressive symptoms in older persons. The Journal of Frailty and Aging, 2(3), $153-164$.

Snook, Brent. (2004). Individual differences in distance travelled by serial burglars. Journal of Investigative Psychology and Offender Profiling, 1(1), 53-66.

South African Police Services. (2014). Common law offences: Definitions. Retrieved 30 March, 2017 from http://www.saps.gov.za/faqdetail.php?fid=302.

United Nations Development Programme. (2003). South Africa: Human development report. Oxford University Press, Cape Town.

Vetten, Lisa. (2014). Rape and other forms of sexual violence in South Africa. Policy Brief NO 72, Institute for Security Studies, Pretoria, South Africa. 
Weisburd, David., Groff, Elizabeth., \& Yang, Sue-Ming. (2012). The criminology of place: Street segments and our understanding of the crime problem. New York, NY: Oxford University Press.

Weisburd, David., \& Amram, Shai. (2014). The law of concentrations of crime at place: The case of Tel Aviv-Jaffa. Police Practice and Research, 15(2), 101-114.

Weisburd, David., Eck, John., Braga, Anthony., Telep, Cody., Cave, Breanne., Bowers, Kate., Bruinsma, Gerben., et al. (2016). Place matters: Criminology for the $21^{\text {st }}$ century. Cambridge: Cambridge University Press.

Wolfgang, Marvin M., \& Ferracuti, Franco. (1967). The subculture of violence towards an integrated theory in Criminology. London: Tavistock.

Wu, Ling., Liu, Xiaodian., Ye, Xinyue., Leipnik, Mark., Lee, Jay., \& Zhu, Xinyan. (2015). Permeability, space syntax, and the patterning of residential burglaries in urban China. Applied Geography, 60, 261-265. 